\title{
STRATEGIES IN IMPROVING READING SKILLS OF UNIVERSITY ENGLISH LEARNERS
}

\author{
Alfian Alfian \\ State Islamic University of Sulthan Thaha Saifuddin Jambi \\ alfian@uinjambi.ac.id
}

\begin{abstract}
Studies on language learning strategies (LLS) have been conducted elsewhere in the world, however, there were very limited studies on student learning strategies in improving reading skills. Therefore, this study is aimed to identify the strategies used in improving reading skills. This case study was conducted by distributing questionaire involving 200 English Education and English Literature students as the sample of this study. The finding of this study demonstrated that the respondent use the LLS, such as memory, metacognitve, compensation, cognitive, affective, and social in improving reading skill. However, most of respondents reported to use metacognitive strategy at the most. The results also indicated that there are five most and five least strategies used by the respondents. This research is very useful as a reference in the framework of developing strategies for reading in tertiary institutions.
\end{abstract}

Keywords. Language learning strategies, reading, language skills

\section{Introduction}

There have been many studies conducted in connection with English learning strategies in various countries including Indonesia, for example (Annurahman, Kurniawati, \& Ramadhiyanti, 2013; Hamra \& Syatriana, 2015; Lengkanawati, 2004; Mattarima \& Hamdan, 2011; Mistar, 2003; Setiyadi, 2004; Wahyuni, 2013; Joseph, 20012).. Research about English learning strategies is generally very useful for the needs of developing or improving teaching and learning. These studies are also very useful for students, and lecturers and curriculum designers, especially for junior high and junior high schools.

At the tertiary level, the general learning strategy including the learning strategies in four skills(listening, speaking, reading and writing) and language components such as vocabulary and grammar are also very beneficial for students and lecturers. The lecturer requires knowledge of how students learn to develop learning. Naiman, (1978) asserts that "All forms of language teaching can be well developed if we have sufficient knowledge about the learner and about the teaching and learning process itself "(p. 1). This is emphasize that the teacher needs to know the ways how the students learn English in all aspects of English including reading skill.

It is generally accepted that reading is the key skill that leads the studens for having a good idea in speaking, listening and especially wrriting. However, reading is also one of the most difficult skills for students. Studies show that Indonesian learners have any difficulties in reading texts (Hamra \& Syatriana 
(2015). This means that some Indonesian learners are unsuccessful in reading. This also supported that there are a lot of English learners who do not succeed or have a very low level of proficiency in english (Alfian, 2018; (Song, 2004).However, student can be success in learning if they have the way to improve their reading skill and it really depends on the learners themselves. Lamb (2004) emphasized that the succces is depending on the students themvelves. These two things emphasize that the success of a student is very dependent on themselves, especially with the selection of ways or strategies employed by students in learning English.

Given the fact the difficulties in reading and the important of strategies in reading, it is extremely essential to remember that the learners need to know the strategies for success in reading. The purpose of learning language itself is to be able to communicate both verbally and in writing, meaning that it concerns all aspects of the language itself. From all aspects of the language, it is clear that the ability to read is a receptive skill which is really needed. It is claimed that the ability to understand English texts well is extremely important because the learners would constantly learn a variety of science and technology. However, in order to understand English texts well, certain strategies are needed. Thus, there have been many research on language learning strategies in general, but among the studies mentioned above there is no a single study that concentrated in student learning strategies in improving reading skills. So that there are not many theories in the literature, especially in Indonesia about how to improve reading ability, while the ability to read in English is one of the skills that is very visible that shows one's success in learning languages. This paper presents the results from current study on student learning strategies to improve reading fluency. The purpose of this study in general is to explore strategies - strategies or ways of student learning in improving reading skills (reading).

\section{Literature Review}

\section{General Strategy in Language learning}

Language learning strategy (LLS) refers to to "the learner's goal-directed actions for improving language proficiency or achievement, completing a task, or making learning more efficient, more effective, and easier" (p. 167). Surely,the strategy contained in the plan, the process of achieving a goal (Sugeng, 2004). This definition adopted by Gringer (2012) who suggested that LLS is "actions undertaken by a language learner to influence the process of second or foreign language acquisition" (p. 484).

\section{The classification of LLS}

The aim of learning strategy research is to identify the strategy used by students. From the various strategies that have been examined, the researchers have grouped these strategies into groups. Rubin (1987) generally classifies learning strategies in 3 types, namely: learning strategies, communication strategies and social strategies. Furthermore, dividing language learning strategies into metacognitive strategies (planning and learning management) and cognitive strategies (use of the mind). 
Other researchers such as Chamot and O'Malley (1990) grouped learning strategies into three groups namely cognitive, metacognitive, and social / affective strategies. Cognitive strategies namely yenag strategies related to the use of thinking power such as grouping words, summarizing, giving explanations, metacognitive strategies namely strategies related to planning and managing and evaluating learning such as planning learning, repeating lessons, carrying out checking checks. Social and affective strategies or strategies related to interaction with others and those related to learner attitudes. For example, talking to friends, helping friends in learning, working together, feeling happy, laughing, complaining, etc. From this grouping it can be seen that Chamot and O` Malley (1990) adopted and modified the strategies put forward by Rubin (1987). Unlike Rubin who classifies strategies in general, they group communication strategies and social strategies into LLS such as positive and metacognitive strategies.

Furthermore Oxford (1990) groups learning strategies into 2 types, namely direct strategy and indirect strategy. The direct strategy by Oxford (1990) is divided into three categories, namely:

1. Memory strategy,Memory strategies are language learning strategies that help learners store and remember new information they have learned. This strategy relies heavily on memory or memory. There are a number of examples included in this strategy, for example connecting sounds to images, making imaginations that frogs can use, using media to remember words, memorizing words or expressions by remembering their location, repeating lessons.2. Cognitive strategy (cognitive strategy).

2. Cognitive strategy is a strategy that relies on the power of thinking of students with which relates to how students process information and manipulate the acquisition of language learned. Examples of this strategy are to practice language naturally, analyze and give reasons, take notes, use media to send and receive message.

3. Compensation (compensation strategy) is a strategy used to cover language deficiencies. Examples of compensation strategies are guessing words, using sign language, using word equations to say something, using dictionaries etc. Second, indirect language learning strategies are strategies that support and regulate the teaching and learning process indirectly. This strategy by Oxford (1990) is also divided into three categories, namely:

4. Metacognitive strategy (Metacognitive strategy). Metacognitive strategy is a strategy that requires planning, observation, and evaluation of learning. So that this strategy is divided into three major parts, namely, concentration of learning, compiling and planning learning and evaluating learning. Examples of this strategy are reviewing and connecting learning material, focusing attention , make learning goals, look for opportunities to practice, monitor their own development and evaluate their own learning progress.

5. Affective Strategy (Affectrive strategy). Affective strategy is a language learning strategy that is related to emotions, character, motivation and self-confidence of students in learning languages. This strategy is also divided into three major parts, namely: reducing anxiety in learning, motivating yourself, managing emotions. Examples of these strategies are deep breathing, using music in learning, writing a diary, and making jokes.

6. Social strategy (Social strategy). Social strategy or social strategy is related to interaction with other people. This strategy is also divided into three major parts, namely asking questions, cooperating with others and empathizing with others. 
An example of this strategy is asking someone to clarify something, working with a friend, asking someone to correct the mistake.

From these two categories of strategies it can be seen that Oxford (1990) adopted and developed the strategies put forward by experts before it (Chamot and O'Malley, 1990; Rubin (1987), so that they became six strategies. Thus from classification / grouping the strategies raised by the experts above can be seen that the Oxford (1990) strategy is more comprehensive, more detailed and covers a wide range and adopts a variety of strategies in language learning proposed by other experts. So that there are very many researchers about language learning strategies currently using the classification developed by Oxford (1990) as a framework for their research theory because it is more comprehensive and more detailed (Ellis, 1994; Rao, 2004; Radwan, 2011). From the Oxford strategy classification (1990), a questionnaire called Strategy has been developed. Inventory for Language Learning (SILL) questionnaire to examine general language learning strategies in the world. And this questionnaire has been used by researchers from various countries in researching students' English learning strategies (Alfian, 2018; Annurahman, 2011; Mattarima, 2013; Al-Buainain (2010), Gharbavi and Mousavi (2012), Javid , Al-Thubaiti, and Uthman (2013), Lim (2013), Radwan (2011), and Wahyuni (2013).

\section{LLS in improving reading skills}

From the six strategies proposed by Oxford $(1990,2011)$, there are 62 general language learning strategies for the language learners to use.Among these strategies there are many strategies that are categorized into strategies which are used to improve reading skills. Oxford (1990) asserts that there are about 52 strategies that can be categorized into strategies to improve reading skills. As stated above, the category of LLS proposed by Oxford are more comprehensive and detailed, so the theory used as the basis of this study refers to the LLS proposed by Oxford (1990).

\section{STUDIESON LLS IN READING SKILL}

LLS, in particular, language skills, help learners perform tasks and improve their skills (Oxford, 1999). Considerable research has conducted studies in this area. To date several findings, in relation to the strategies used in reading skill, have been identified. Below is the review of several studies on the strategies used in the learning of the reading skill.

Studies on strategies used in the development of reading skills have also been the focus of studies in the LLS domain. It is believed that the strategies use in reading can be different across individual characteristics that may influence reading performance. This means that it is possible for a reader to process a text differently, according to the purpose, attitude, interest, and background knowledge of the individual reader (Phakiti, 2003). On another note, according to Rao (2004), most studies on reading strategies focus on the cognitive and metacognitive categorised by Chamot and O`malley (1990) and Oxford (1990). Several of these studies on these reading strategies will be reviewed in depth below. 
Zhang (1999) investigated the strategy of metacognitive of second language learners to find the relationship between learners' strategy and their use of the strategies when undertaking designated tasks. He investigated 312 Chinese EFL readers in his study, using the EFL reading strategy inventory. He found that the Chinese EFL learners tended to employ global strategies, for example to guess meaning through inferences and area strategies, for example focusing on the meaning of word. He also found that global strategy is also employed by effective readers. In another study, Zhang (2001) did a study in the metacognitive reading strategies used by 10 Chinese EFL learners. He used Chinese students' college test scores to classify the learners. The results indicated that the high scoring students showed clearer awareness of the strategies used as compared with the low scoring students who demonstrated that they were unaware of the need to use different reading strategies to help them with solving the reading problems they encountered. He found that high scorers tended to use anticipated text contexts, monitored comprehension and skimming tactics to identify the main ideas, whilst low scorers demonstrated higher use of local strategies such as rereading sentences, using dictionaries and translating into L1.

Rao, Gu, Zhang, Hu ( 2005) investigated primary school learners in the use of reading strategies. The think aloud protocol was used to collect the data and the student approach to learning (SAL) framework was used to analyse the data. It was found that successful learners used deep processing strategies, such as differencing, prediction, reconstruction questioning of the text which is similar to positive reading strategies identified by Pardon and Waxman (1988). The other finding of Rao et al (2005) was that less successful learners used surface level processing strategies, such as paraphrasing, rereading and questioning the meaning of the word or phrasing. These findings of Rao et al (2005) are similar to the strategies used in Murphy (1985) in which prediction and paraphrasing were used by the learners when developing their listening skills. HoweverMurphy (1985) did not differentiate in terms of which proficiency levels were achieved as a consequence of these strategies.

Another current study on reading strategies was by Phakiti (2003). Phakiti (2003) conducted study on the relationship between metacognitive and cognitive strategies used by learners to achieve EFL reading competency. This study involved 384 Thai university students who finish completed reading test and a questionnaire on their metacognitive and cognitive use. Phakiti (2003) also interviewed 4 highly successful learners and 4 less successful learners. The findings showed that successful learners employ higher metacognitive strategies than moderately successful learners and that less successful learners employ less metacognitive strategies.

Language Learning strategies used by learners studying in the reading Skills have been reviewed. The strategies used in the reading skill areas have been reviewed by comparing several studies. This has been done to build the conceptual and theoretical foundations for the current study. Such a literature focus relates to research questions about strategic performances in the reading skills. 


\section{Method}

This case study describes the conditions and activities that exist in students related to the strategies of language learning in improving reading. The participants of this study were university language learners in the sixth semester. It is estimated that the sample of this study were 200 students. The selection of sixth semester students is because they have studied English for three years and are assumed to know a lot about language learning strategies in improving reading ability, especially students who have succeeded in learning English . Agno (2010) emphasizes that length of study is very closely related to the proficiency selection of learning strategies. Another reason for this election is related to the ease of communication in which the 6th semester students are still taking the courses so that they are easy to be contacted.

\section{Data collection data analysis}

The data for this stduy were collected by distributing questionnaire and conducted an interview. The questionaire used in this study was Strategy Inventory for Language Learning (SILL) version 7.0, which was developed by Oxford (1990). This SILL is questionaire to assess general English learning strategies which include the four skills (listening, speaking reading and writing) as well as the language, grammar and vocabulary components. In this study the statements in SILL have been adjusted to assess strategies in improving reading skill. This questionnaire contains the language learning strategies that use a Likert scale. This means that students will choose a response from the statement, such as: 1 . Strongly disagree 2. Disagree 3. Fairly Agree 4. Agree 5. Strongly Agree. In terms of data analysis, SPPS (statistical product for Social science) a software developed by IBM was used to analyze the data from questionnaire. Descriptive data such as mean frequency and percentage are used to identify the level of strategy usage.

\section{Result and discussion}

The first question from this research is to look at strategies in improving reading skills. Data obtained to answer this question, taken from a questionnaire from the Strategy Inventory for Language Learners (SILL) compiled by Oxford (1990). The results of the questionnaire showed that all strategies found by oxford were widely used by students which are described in table 1 . Table 1 presents the frequency of 6 strategies used by participants collected through surveys. The mean / average indicates the strategy used by each respondent.

Tabel 1. Mean dan standar deviasi dari strategi-strategi yang digunakan oleh mahasiswa.

Descriptive Statistics

\begin{tabular}{|l|l|l|l|l|l|}
\hline & $\mathrm{N}$ & Minimum & Maximum & Mean & Std. Deviation \\
\hline Memorymean & 284 & 2,44 & 5,00 & 3,7561 &, 46850 \\
cognitivemean & 284 & 2,00 & 4,78 & 3,6032 &, 55286 \\
compensationmean & 284 & 1,00 & 5,00 & 3,4448 &, 75484 \\
metacognitivemean & 284 & 2,43 & 5,00 & 4,1595 &, 51774 \\
Affectivemean & 284 & 1,80 & 5,00 & 3,6792 &, 65168
\end{tabular}


Socialmean

Valid N (listwise)

284
284

1,33

5,00

3,9419

, 69000

From this table it is clear that all strategies were used by respondents in improving reading skills. However, the most widely used strategy is cognitive strategy. This can be seen from the mean (mean) $M=4.16$. which is the highest mean. While the lowest average strategy is cognitive strategy $\mathrm{M}=3.60$. But it can be concluded that in addition to the most widely used metacognitive strategies, the five strategies are also used in the average range of 3.5 and above.

From the results of the average of the six strategies as contained in table one, it shows that all learning strategies in improving reading are important strategies in improving reading skills. This is in line with what Oxford (1990) found that the average strategy used above 3.5 is a strategy that is always used and includes a high level of strategy use (high frequency use).

The results of this study are the same as some of the other studies in the world that metacognitive strategies are the most widely used strategies in improving reading skills such as the research conducted by Phakiti (2003) and Zang (2001) Anderson (2003). There are several reasons why the results of this study have in common with the results of other studies. One reason is that most of the strategies used in improving reading skills are metacognitive strategies. Furthermore, as stated above that Metacognitive is a very high-value strategy which means that this strategy is a favorite of students in improving their reading ability. These metacognitive strategies are classified into the "Indirect strategies" Direct Strategy. This strategy is a strategy in which students plan, monitor and evaluate the progress of their learning. The students prefer to improve their reading skills by compiling and supporting their learning without involving English directly (Oxford, 1990). Furthermore, metacognitve strategy is a strategy that involves thinking about the reading process, monitoring comprehension when reading, planning to read and evaluating the reading process. O'Malley \& Chamot, 1990; Wenden, 1991; Young \& Oxford, 1997).

Students who use this strategy as mentioned above usually plan, structure, and evaluate their learning. Besides Metacognitive, all strategies used by students indicate that they are active strategy users or actively use English learning strategies to improve their reading skills.

\section{The most and the less individual strategies used}

The second research question is related to the individual or strategy items in SILL that are the most widely used and the least used by students. The strategies that are most widely used really help teachers in designing learning materials that are in accordance with the strategies that are widely used. It also greatly helps students improve reading skills. To get the many and the least used strategies, the mean score or mean / average of the 50 statements in SILL is ranked. Mean scores are ranked or ranked. The 5 highest scores and the five lowest values are taken.

\footnotetext{
Strategies - the strategies most widely used by students in improving reading skills.
} 
Here are the five strategies that the most often used by students which have a mean score between 4.11 to 4.45 as shown in table 2 below.

\begin{tabular}{|l|l|l|l|l|l|l|l|}
\hline & N & & $\begin{array}{l}\text { Std. } \\
\text { Deviat } \\
\text { ion }\end{array}$ & $\begin{array}{l}\text { Minim } \\
\text { um }\end{array}$ & $\begin{array}{l}\text { Maximu } \\
\text { m }\end{array}$ \\
\cline { 2 - 6 } & Valid & Missing & Mean \\
\hline $\begin{array}{l}\text { ST4Q4_I try to find out how to be a better learner of } \\
\text { English }\end{array}$ & 284 & 0 & 4,54 &, 630 & 2 & 5 \\
$\begin{array}{l}\text { ST4Q3_I have clear goals for improving my English skills } \\
\text { ST4Q2_I notice my English mistakes and use that }\end{array}$ & 284 & 0 & 4,43 &, 703 & 2 & 5 \\
$\begin{array}{l}\text { information to help me do better } \\
\text { ST5Q1_I try to relax whenever I feel afraid/ nervous of } \\
\text { using English }\end{array}$ & 284 & 0 & 4,14 &, 798 & 1 & 5 \\
ST2Q4_I use English words I know in different ways. & 284 & 0 & 4,11 &, 790 & 1 & 5 \\
\hline
\end{tabular}

As stated in the table above that the most widely used strategy is "I try to find out how to be a better learner of English" I I try to get how to be a good learner ". This strategy is in the metacognitive strategy category. There are 3 strategies categorized into metacognitive strategies, e.g. "I try to find out how to be a better learner of English", "I have clear goals for improving my English skills", "I notice my English mistakes and use that information to help me do better" $^{\prime \prime}$. While the other two strategies are categorized into the cognitive and affective strategies.

\section{Strategies - the strategies that are least used by students in improving readingability}

Based on the analysis, there are five strategies that are used less often by students in improving reading skills. Strategies that are yhe least used by students have a mean score between 2.90 to 3.26 as shown in table 3 below.

\begin{tabular}{|c|c|c|c|c|c|c|}
\hline & \multicolumn{2}{|l|}{$\mathrm{N}$} & \multirow[b]{2}{*}{ Mean } & \multirow{2}{*}{$\begin{array}{l}\text { Std. } \\
\text { Devi } \\
\text { atio } \\
\mathrm{n}\end{array}$} & \multirow[b]{2}{*}{ Min } & \multirow[b]{2}{*}{ Max } \\
\hline & Valid & Missing & & & & \\
\hline $\begin{array}{l}\text { ST2Q8_I write notes, messages, letters, or reports } \\
\text { in English. }\end{array}$ & 284 & 0 & 3,26 & ,921 & 1 & 5 \\
\hline $\begin{array}{l}\text { ST1Q6_I use flashcards to remember new } \\
\text { English words. }\end{array}$ & 283 & 1 & 3,18 & $\begin{array}{l}1,01 \\
8\end{array}$ & 1 & 5 \\
\hline $\begin{array}{l}\text { ST2Q10_I look for words in my own language } \\
\text { that sound like new words in English }\end{array}$ & 284 & 0 & 3,13 & $\begin{array}{l}1,01 \\
0\end{array}$ & 1 & 5 \\
\hline $\begin{array}{l}\text { ST5Q5_I write down my feelings in a language- } \\
\text { learning diary }\end{array}$ & 284 & 0 & 2,92 & $\begin{array}{l}1,23 \\
4\end{array}$ & 1 & 5 \\
\hline $\begin{array}{l}\text { ST3Q4_I read English without looking up every } \\
\text { new word. }\end{array}$ & 283 & 1 & 2,90 & $\begin{array}{l}1,04 \\
0\end{array}$ & 1 & 5 \\
\hline
\end{tabular}

Table 3 above shows the strategies that are least used by students. As shown in the table above, the least used strategy is "... read English without looking up every new word" which is a group of compensation strategies. Next is "I write down my feelings in a language-learning diary" followed by the strategy "I look for words in my own language that sounds like new words in English" which is a group of cognitive strategies. Then the last two strategies that are very rarely used are "I 
write notes, messages, letters, or reports in English" and "I use flashcards to remember new English words".Each of these strategies is categorized in the cognitive and memory strategy. Of the six major groups of strategies put forward by Oxford (1990) (Memory, cognitive, compensation, metacognitive, affective and social strategies) none of the dominant participants were less interested.

\section{Discussion}

The results of this study indicate that the six strategies to improve reading skills proposed by Oxford (1990) are used by the students equally. From the results of the average of the six strategies as listed in table 1, shows that all language learning strategies in improving reading are important strategies in improving reading skills. This is in line with what Oxford (1990) found that the average strategy used above 3.5 is a strategy that is always used and includes a high frequency use.

The results of this study demonstratedthat there wasa high frequency of strategy used. Metacognitive strategies was used at the highest frequency. The result of this study is similar to the other research findings in which metacognitive strategies that are most strategies used in improving reading skills, such as the study conducted by Phakiti (2003) and Zang (2001) Anderson (2003).

There are several reasons why the results of this study have similar results with the results of other studies. One of the main reasons is that as stated above that Metacognitive is a direct strategy in which students plan, monitor and evaluate the progress of their learning. This is a very important thing in a learning process because the success of learning, it should have a plan, supervision / monitoring and evaluate the learning process in order tto see the effectiveness of learning. The similarity of the results of this study with other research results also shows that students in this study prefer to improve their reading skills by compiling and supporting their learning without involving English directly (Oxford, 1990).

Furthermore, metacognitve strategy is a strategy that involves thinking about the process of reading, monitoring comprehension when reading, planning to read and evaluating the reading process (O'Malley \& Chamot, 1990; Wenden, 1991; Young \& Oxford, 1997). Students who use this strategy as mentioned above usually plan, structure, and evaluate their learning. Besides Metacognitive, all strategies are used by students in improving reading skills. This indicates that they are active strategy users or actively use English learning strategies to improve their reading skills.

Regarding the strategies most widely used from the sub-strategies it can be found that "I try to find out how to be a better learner of English and I have clear goals for improving my English skills"are the strategy that the most reported by students. This shows that in improving the reading ability of students, they try as much as possible to improve their reading ability in various ways including having clear goals in improving their reading ability. The highr frequency of the strategies used is very closely related to the status of participants in this study in which the participants are prospective English teachers. As prospective English teachers, of course they are required to improve their English language skills, 
especially their reading skills. This is in line with the research on language learning strategies proposed by Alfian (2018) where English students who are prospective English teachers choose to share ways or various strategies to improve their English skills. This is very useful in increasing their ability to teach not only English but also in teaching learning strategies to their students later.

Furthermore, strategies to look for various ways / strategies to improve reading skills are very closely related to "strategy awareness" or awareness in looking for strategies to improve reading skills and improve English skills in general. Lee and Oxford (2008) assert that awareness strategies or awareness of the importance of strategies really help language learners in improving their abilities so that they use these strategies appropriately. This will also bring students to become good language learners.

Reflections from the results obtained indicate that prospective English teachers in this study have realized the importance of strategies that can be used in improving their reading skills. Some strategies that they consider to be very important as contained in the results of this study such as reading English books, conducting discussions with other English learners (Oxford, 1990).

Furthermore, the least used strategy is "I read English without looking up every new word". This strategy, according to the grouping strategy presented by Oxford (1990) is included in the category of Compensation strategy, where language learners try to overcome their limitations by doing things that can improve their understanding of learning. Students do not look at dictionaries to find difficult words in reading comprehension. This shows that students use other strategies in overcoming the limitations of English vocabulary. Thus it can be concluded that the participants prefer to guess the meaning of words by looking at the context of the sentence. But the use of a dictionary only depends on the situation or if they really do not understand the meaning of the word, then they need a dictionary. This result is supported by the results of the research conducted by Mistar (2002) and Wahyuni (2013) who found that participants did use dictionaries in reading if they were unable to guess the meaning of words at all.

\section{Conclusion}

The results showed that English Education students had employed all six language learning strategies to improve reading skills. However, there are several strategies put forward by Oxford (1990) which are widely used and few are used by students. From the interviews it was found that the students in this study used strategies, read (metacognitive strategies), used dictionaries (compensation strategies), translated into Indonesian (Cognitive), guessed the meaning of words (compensation), underlined difficult words and wrote in in a notebook. (Cognitive strategy).From the results of this study it can be concluded that the learners already have many strategies, several strategies to improve the reading ability.

As the conclusion, the findings that have been produced in this study, there are several things that can be found as follows: First, in improving reading skills in English, students have used a variety of strategies or ways that they think can improve their abilities. This is a useful input for anyone who wants to improve reading skills in English and who work in the field of language teaching. Students 
who are less successful in improving reading skills can use strategies that have been advanced by successful students. Furthermore, lecturers who teach reading courses can use the results of this study to provide input to other students and can develop curriculums of Reading courses in accordance with the strategies used by learners.

\section{References}

Al-Buainain, H. (2010). Language learning strategies employed by English majors at Qatar University: questions and queries. IIUM Journal of English Language and Literature, 4(2), 92-120.

Alfian, A. (2018). Proficiency level and language learning strategy choice of Islamic University learners in Indonesia. TEFLIN Journal, 29(1), 1-18.

Alhaisoni, E. (2012). Language learning strategy use of Saudi EFL students in an intensive English learning context. Asian Social Science, 8(13), p115.

Anderson, N.J., 2003. Metacognitive reading strategies increase L2 performance. The Language Teacher 27, 20-22.

Anderson, Neil J. 2003. Sscrolling, clicking, and reading English: online reading strategies in a second/foreign language. The Reading Matrix Vol.3. No.3.

Annurahman, kurniawati, T., \& Ramadhiyanti, Y. (2013). Exploring Indonesian college students strategies in Learning English Language AWEJ, 4(3), 317 -330 .

Aqli, B., Padmadewi, N., \& Suarnajaya, W. (2013). The practice of English language teaching and learning in sekolah Buin batu PT. Newmont Nusa Tenggara, Wes Sumbawa, NTB Province. E-Journal program Pasca Sarjana Universitas Ganesha, 1.

Baradja, M. F. (1994). memperkenalkan pemerolehan bahasa kedua (Introducing second language acquisition). Jurnal pendidikan Humaniora dan sains, 1(1), 2-12.

Buska, W., Prihartini, Y., \& Hasnah, N. 2018. Analysis of Students' Arabic Proficiency for Vocabulary Mastery in State Islamic Junior High School in Muaro Jambi. Innovatio: Journal for Religious Innovation Studies, 18(1), 51-62.

Griffiths, C. (2003). Patterns of language learning strategy use. System, 31(3), 367-383. doi: 10.1016/s0346-251x(03)00048-4

Hamra, A., \& Syatriana, E. (2015). Developing a model of teaching reading comprehension for EFL students. TEFLIN journal, 21(1), 27-40.

Lee, K. R., \& Oxford, R. (2008). Understanding EFL learners' strategy use and strategy awareness. Asian EFL Journal, 10(1), 7-32.

Lengkanawati, N. S. (2004). How learners from different cultural background learn a foreign language. The Asian EFL Journal, 1(1), 2-8.

Magno, C. (2010). Korean students' language learning strategies and years of studying English as predictors of proficiency in English. TESOL Journal, 2, 39-61.

Mattarima, K., \& Hamdan, A. R. (2011). Understanding students learning stratrgies as an input context to design English Classroom activities. 
International Journal of Psychological Studies, 3(2), 328-348.

McLaughin, B. (1990). The relationship between first and second languages: Language proficiency and language aptitude. In P. B. Harley, J. P. Allen, S. Cummins \& M. Swain (Eds.), The development of second language proficiency Cambridge: Cambridge University Press.

Mistar, J. (2003). Strategies of Indonesian learner of English across individual differences. (Doctoral Degree), Monash University.

Naiman, N., Fröhlich, M., Stern, H. H., \& Todesco, A. (Ed.). (1978). The Good Language Learner. Toronto, Canada: Ontario Institute for Studies in Education Press.

Nakatani, Y. (2006). Developing an Oral Communication Strategy Inventory. The Modern Language Journal, 90(2), 151-168. doi: 10.1111/j.15404781.2006.00390.x

O’Malley, J.M. and Chamot, A.U. (1990) Learning Strategiesin Second Language Acquisition. Cambridge: Cambridge University Press

Oxford, R. L. (2011). Strategies for learning a second or foreign language. Language Teaching, 44(02), 167-180.

Oxford, R. L., \& Burry-Stock, J. A. (1995). Assessing the use of language learning strategies worldwide with the ESL/EFL version of the Strategy Inventory for Language Learning (SILL). System, 23(1), 1-23.

Prihartini, Y., \& Wahyudi, W. (2018). The Development of Integrated Learning Model To Improve Language Skills at Arabic Language. IJER (Indonesian Journal of Educational Research), 3(1), 9-14.

Prihartini, Y., Wahyudi, W., Aliasar, A., Mukhaiyar, M., \& Ungsi, A. O. M. (2018). The Development of Arabic Learning Model by Using Multimedia of Computer at UIN STS Jambi. Al-Ta lim Journal, 25(2), 135-143.

Rubin, J., \& Thompson, I. (1982). How to be a more successful language learner. Boston, MA: Heinle \& Heinle

Setiyadi, A. B. (2004). Redesigning language learning strategy classifications. TEFLIN Journal, 2(15).

Song, X. (2004). Language Learning Strategy use and performance for Chinese learners of English. (Master), Queen University, Kingston.

Wahyuni, S. (2013). L2 Speaking Strategies Employed by Indonesian EFL Tertiary Students Across Proficiency and Gender: University of Canberra.

Yusuf, S. (2012). Language learning strategies of two Indonesian young learners in the USA. International Journal of Apllied Linguistics, 2(4), 65-72.

Young, D.J. andOxford,R.L. (1997). A gender-related analysis of strategies used to process written input in the native language and a foreign language. AppliedLanguage Learning 8 (1), 43-73.

Wahyudi, W., \& Prihartini, Y. (2019, April). Development of Arabic Learning Material Based on Eclectic Method. In 3rd Asian Education Symposium (AES 2018). Atlantis Press

Wenden, A.L. (1991) Learner Strategies for Learner Autonomy. London: Prentice-Hall. 